\title{
Criminal-Legal and Criminological Overviews of Kosovo Citizen's Participation in Armed Conflicts in Syria and Iraq
}

\author{
Professor Azem Hajdari \\ Faculty of Law, University of Prishtina "Hasan Prishtina”, Pristina, Kosovo
}

Received: September 7, 2016 Accepted: September 24, 2016 Published: September 25, 2016

doi: $10.5296 /$ jsss.v4i1.9997

URL: http://dx.doi.org/10.5296/jsss.v4i1.9997

\begin{abstract}
The criminal offence of Kosovo citizen's participation in armed conflicts outside of the country has been included in Kosovo criminal legislation in 2015. It has been addressed by a special law and this was determined due to the inclusion of a considerable number of Kosovo citizens in armed conflicts in Syria and Iraq. A perpetrator of this criminal offence can be any person that is a Kosovo citizen, whereas their incriminating actions shall be punishable from 6 months up to 15 years of sentence by imprisonment. Conducted researched for this criminal offence prove in armed conflicts in Syria and Iraq are currently 314 Kosovo citizens, among them also 27 children and 38 women. Kosovo citizens included in these conflicts exercise their military action mainly in support of terrorist organizations ISIS, SALUSTRA etc. In these conflicts until now died 57 Kosovo citizens. Concerning this criminal offence The State Prosecution has issued 34 decisions on implementing investigations, whereas courts did not yet promulgated any judgment punishing its perpetrators. The causes of Kosovo citizen's participation in armed conflicts in Syria and Iraq are different, but dominate those economic, ideological, the poor work of justice bodies and media. This criminal offence causes numerous consequences of political, psychological, personal and family character.
\end{abstract}

Keywords: Kosovo, Armed conflicts, ISIS, SALUSTRA, Syria, Iraq

\section{Introduction}

Kosovo citizen's participation in armed conflicts in Syria and Iraq is a concern requiring a clear and addressing resolution of competent state authorities. In this context must be seen the issuance of the Law on the Prohibition of the Union in Armed Conflicts Abroad as well as the arrest and issuance of 34 decisions in implementing investigations for commission of the criminal offence of Kosovo citizen's participation in armed conflicts abroad. The respective law has regulated criminal-substantial key issues concerning this criminal offence (who can 
be a perpetrator, perpetrating actions, criminal liability and criminal sanctions) as well as made concrete references of several criminal-procedural issues (application of procedures regarding confiscation of property as well as intrusive covert and technical measures of surveillance and investigation). According to this law a perpetrator of this criminal offence can be only a citizen of Kosovo, whereas the sentence that shall be imposed to a responsible person is up to 15 years of imprisonment. Researchers conducted prove that currently in armed conflicts in Syria and Iraq are 314 Kosovo citizens, which develop military activities in support of terrorist organizations ISIS, SALUSTRA etc. 54\% of these citizens have gone to these countries in 2013. Among Kosovo citizens who are in Syria and Iraq are also 27 children and 38 women, some of which have been included directly in armed operations. So far in these fighting have been killed 57 Kosovo citizens. Consequences of commission of the criminal offence of Kosovo citizen's participation in armed conflicts abroad are of political, psychological, personal and family character. The causes of Kosovo citizen's participation in military conflicts in Syria and Iraq are multidimensional. They are of economic, ideological, micro-group, poor work of justice bodies and those related to the misuse of public media character, especially of social networks. As abovementioned, concerning this criminal offence until now have been issued 34 decisions upon implementation of investigation, whereas it was not concluded any judicial process that would result with any imposition of judgment.

\section{Several Criminal-Legal Characteristics of the Criminal Offence of Kosovo Citizen's Participation in Armed Conflicts Abroad}

The criminal offence of Kosovo citizen's participation in armed conflicts abroad has been regulated by the Law on the Prohibition of the Union in Armed Conflicts Abroad (Note 1). This offence, as any other criminal offence is manifested through particular criminal-legal characteristics. In the following of this scientific paper shall be discussed about the meaning, perpetrators, criminal liability and criminal sanctions.

\subsection{Meaning}

In Kosovo criminal legislation and legal literature is not given any clear and complete definition of notion of the criminal offence of Kosovo citizen's participation in armed conflicts abroad. This due to the fact in this country the criminal actions establishing this criminal offence have been incriminated since May of 2015, so currently there is a lack of scientific treatments of this criminal offence from authors of criminal law. "Probably a clearer definition of concrete variants of this criminal offence it could have been done especially in criminal codes of countries which commenced earlier than Kosovo to face with the problematic of participation of their citizens in armed conflicts of third countries (Note 2). Consequently, by criminal offence of Kosovo citizen's participation in armed conflicts abroad is implied actions through which is made organization, recruitment, funding, incitement, leading or trainings of persons or groups of persons with the purpose of joining or participating in foreign military of police, in foreign paramilitary or police formations, in individual or group organizations, in any form of armed conflicts abroad of territory of the Republic of Kosovo. These are actions through which is violated state interest and national security of country (article 2). In fact, it is about actions which shall be committed in direct and indirect manner, public, written, audio-recordings etc. (Note 3 ). 


\subsection{Perpetrators}

A perpetrator of crime shall be considered the person who has committed it (Note 4). Observed from legal definition, a perpetrator of criminal offence of Kosovo citizen's participation in armed conflicts abroad can be any person who is a citizen of Kosovo which participates or organizes, recruits, finances, incites, leads, or trains persons or group of persons with the purpose of joining or participating in abroad army or police, in foreign paramilitary or police formations, in individual or group organizations, in any form of armed conflicts abroad of territory of the Republic of Kosovo (Note 5). A perpetrator of the criminal offence of Kosovo citizen's participation in armed conflicts abroad shall be considered also any person-Kosovo citizen which publicly, in the meeting or by writing audio-visual recordings, by including and not limited to social networks or in any other form of communication, invites or incites others for commission of actions establishing this offence or which conceals or does not report for preparation of a criminal offence and shelters or helps the perpetrator to avoid detection, arrest, concealment of evidences etc. Therefore in any case when it comes to this criminal offence, as a perpetrator shall be considered a Kosovo citizen which undertakes abovementioned actions or omissions and thus endangers state interest and Kosovo national security.

\subsection{Criminal Liability}

A person shall be considered criminally liable when at the time of commission of criminal offence was responsible (meaning had psychological attributes-capacities that make possible to understand the importance of offence and to control its behaviors) and guilty (when to the offence had that kind of relation which makes it possible to be charged with, respectively when considers the offence as its own) (Note 6). Observing in general terms the criminal liability related to guilt exists only when a criminal offence has been committed by intent or negligence.

Under applicable legal solutions, criminal liability for the commission of criminal offence of Kosovo citizen's participation in armed conflicts abroad exists only when it is committed by intent. So the criminal liability for this type of criminal offence it cannot result from actions committed by negligence. This due to the nature of actions itself through which shall be committed the offence in question. Observing in these terms organization, recruitment, leading, training etc., of persons to participate in foreign army or police or searching, offering and collection of funds, holding lectures, hiding the perpetrator and evidences etc., does not constitute actions that could have been committed by negligence. By analyzing all this we come to the conclusion that criminal liability of perpetrators of the criminal offence of Kosovo citizen's participation in armed conflicts abroad anytime shall be handled in the context of intent as the most severe form of guilt, but always in relation by type of the committed action and the degree of risking values protected by the law.

Consequently, in order for a perpetrator of the criminal offence of Kosovo citizen's participation in armed conflicts abroad to become subject of criminal liability is sufficient for him to have committed only one prohibition action, which by law is determined as such. So, only a special criminal act can be prosecuted and the perpetrator which have committed it shall be imposed a respective criminal sanction. 


\subsection{Criminal Sanctions}

Criminal sanctions are enforced measures applicable by violence and represent repression against perpetrator of criminal offence. Through criminal sanctions to the perpetrator of criminal offence shall be limited and taken rights, freedoms and other very important values such as the freedom of movement, property etc., In modern society there are numerous types of criminal sanctions. Their goal is to protect society from criminality (Note 7).

By the Law on Prohibition of the Union in armed conflicts abroad has been foreseen that against perpetrators of the criminal offence of Kosovo citizen's participation in armed conflicts abroad depending on the committed action and the degree of risking security and Kosovo national security, to be imposed the sentence by imprisonment punishable from 6 months up to 15 years.

The height of threatened punishment for the commission of this criminal offence is considered to be relatively high, but of course in full accordance with the degree of risk this offence it represents for society. The causes determined this height of punishment are related to a relatively large number of Kosovo citizen's participation in armed conflicts in Syria and Iraq, but also with the existence of many circumstances that favor other persons to join armed organizations in these two countries (religious affiliation, innocent victims sensitivity etc.).

Besides sentence by imprisonment the legislator made clear the fact that concerning the criminal offence of Kosovo citizen's participation in armed conflicts abroad shall be applicable also procedures of seizure or confiscating of property determined by the Criminal Procedure Code and the Law on Extended Powers for confiscating of assets acquired by criminal offence (Note 8).

\section{Several Phenomenological Data Concerning the Criminal Offence of Kosovo Citizen's Participation in Armed Conflicts Abroad Related to Conflicts in Syria and Iraq}

A genuine research of criminal offences it cannot be imagined without doing scientific researches of several phenomenological aspects. This conclusion is valuable also for the criminal offence of Kosovo citizen's participation in armed conflicts abroad. By bearing in mind this fact, in the following of this scientific paper shall be discussed about the forms of commission of this criminal offence volume and dynamics, consequences and several personal data of its perpetrators. Addressing these issues, in lack of the data for convicted persons, shall be done on basis of data for arrested and detained persons for whom the state prosecutor has issued a decision on application of investigation.

\subsection{Forms of Commission}

Forms of commission of the criminal offence of Kosovo citizen's participation in armed conflicts abroad are numerous and diverse. They consist in participation, organization, recruitment, leading or training of persons or group of persons with the purpose of joining or participating in a foreign army or police, in group or individual organizations of any forms whether related to armed conflicts taking place outside of the territory of Republic of Kosovo, or searching, offering and collection of funds or other material benefits in order to use them totally or partially to achieve the effects of respective incriminating actions; call or incitement in a public manner, in meeting or by writing, audio-visual shooting, by including and not limited to social networks or in any other form of communication to participate in armed 
conflicts abroad, conceal or does not report for preparation of a criminal offence and shelters or helps the perpetrator to avoid detection, arrest, concealment of evidences or in any other way or sheltering a certain person or undertaking the actions to prevent arrest or execution of punishment.

Modest results of this scientific paper prove in Kosovo from 2013 onwards almost were manifested all the above mentioned forms of commission of the criminal offence of Kosovo citizen's participation in armed conflicts abroad, especially in conflicts in Syria and Iraq. Imams of mosques and other persons in many Kosovo environments by taking advantage of their positions and provided possibilities to have contacts with many people incited and manipulated numerous persons on their path towards these two countries in order to give "their contribution" in "The Holy War" for "Islamic Jihad". They become part of terrorist organizations such as ISIS, SALUSTRA etc., through persons which until recently walked freely from Kosovo without any fear and obstacle (Note 9). This is proven by the fact of arresting more than 40 persons (imams, owner of means of public information such is the case of owner of a radio in Peja, leaders of political parties such is the case with the President of movement LIZBA Fuad Ramiqi etc.) which police authorities arrested on September, 2014 (Note 10) as well as the fact of conducting criminal proceedings against 34 other persons which currently are in detention on remand in Kosovo) (Note 11). Of course, the biggest concern related to this criminal phenomenon consists in the fact of participation of 314 persons from Kosovo in armed conflicts currently taking place in Syria and Iraq (Note 12). These figures, although may not be complete, should represent a concern for responsible authorities in combating crime in the country in order to undertake all legal measures guaranteeing a successful fight against this criminal phenomenon.

\subsection{Volume and Dynamics}

Volume and dynamic of criminality in general, respectively of a certain type of criminal offences represent a criminological category through which is aimed to present the level and movement of respective criminal phenomenon through years and particular regions of a country or even beyond. In order to fulfill this goal, in the following of this scientific paper, shall be handled the volume and dynamics of the criminal offence of Kosovo citizen's participation in armed conflicts abroad, respectively in conflicts in Syria and Iraq.

Handling of volume of criminal phenomenon of Kosovo citizen's participation in armed conflicts in Syria and Iraq as its purpose has reflection of presence level of such phenomenon in country. Of course, a real level presentation of this criminal phenomenon is a problem as complex and challenging as well as insoluble. "This due to the fact the accurate volume of criminality presented at society, regardless of formal evidences, it almost cannot be known, because it is never evidenced entirely, is not known completely, due to the different circumstances reigning at society" (Note 13). By bearing in mind the fact also to this type of criminal offence are present these circumstances, then also statistical data which we refer concerning its volume must be seen by this aspect with reservations, which typically are present in researches of this kind. 
Nevertheless, for the purposes of this scientific paper, in a special table shall be presented data concerning Kosovo citizens evidenced number which currently participate in armed conflicts in Syria and Iraq and the number of criminal reports filed for the commission of criminal offence of Kosovo citizen's participation in armed conflicts abroad (Note 14).

Table 1. The data on number of participants in conflicts in Syria and Iraq

\begin{tabular}{ll}
\hline Number of participants in conflicts in Syria and Iraq & Number of criminal reports \\
\hline 314 & 34 \\
\hline
\end{tabular}

Also, in the context of manifestation through years Kosovo Police official statistics prove that criminal phenomenon of Kosovo citizen's participation in armed conflicts abroad, respectively in conflicts in Syria and Iraq is mostly manifested in 2013 when considered to have been gone about $54 \%$ of Kosovo citizens that currently are participants in these armed conflicts (Note 15).

According to these data in armed conflicts in Syria and Iraq currently participate 314 Kosovo citizens, and concerning this criminal phenomenon in the country have been filed 34 criminal reports for which The State Prosecution has issued a decision for the investigations. This number of evidenced persons as participants in armed conflicts abroad or against which have been filed criminal reports, by having in mind the level of public opinion perception concerning the presence of this criminal phenomenon is estimated to be unrealistic. In meanwhile the cause why in 2013 there is the biggest number (54\%) of Kosovo citizens from general number of those which is considered to be included in conflicts in Syria and Iraq must be sought in the fact during this year ISIS and other organizations included in armed conflicts in these two countries were quite good consolidated and recruitment within their organizations were more intensified.

\subsection{Circumstances}

The criminal offence of Kosovo citizen's participation in armed conflicts abroad causes numerous and diverse circumstances. Circumstances caused by this criminal offence in general may be of a political, psychological, family, individual nature etc.

Political circumstances of criminal phenomenon of Kosovo citizen's participation in armed conflicts abroad, respectively conflicts in Syria and Iraq are multi-dimensional. They as long as this phenomenon is not handled by institutions appropriately, can affect in the country's Euro-Atlantic integration processes. Therefore, political state and religious leaders should give clear messages of punishment of any action by means of which is committed the criminal offence of Kosovo citizen's participation in armed conflicts abroad. They have to use all available mechanisms in order to display the circumstances having this criminal phenomenon for Kosovo, region and perhaps beyond. On the other hand, this criminal phenomenon may affect adversely in traditionally good relations existing between communities and religious groups operating in Kosovo. Therefore, it is a responsibility of leaders and other influential people within the Muslim religion to advance the degree of promotion of religious tolerance and ignoring individuals prone to participate in armed 
conflicts developed on behalf of religion. They should apply restrictive policies to mosque imams which through their lectures support ideological wars.

This criminal phenomenon may manifest consequences also in the field of Rule of Law. Kosovo continues to have evident problems in this regard, so the unsatisfactory level of detection and conviction of perpetrators of the criminal offence of Kosovo citizen's participation in armed conflicts abroad it shall just deepen the crisis in which is the criminal justice system of country. In conditions when terrorist organizations ISIS, SALUSTRA etc., have considerable financial funds, and this related to a relatively high corruption level existing in the field of Kosovo judiciary, it cannot be excluded the possibility of a possible cooperation between them (Note 16).

Except political consequences the criminal offence of Kosovo citizen's participation in armed conflicts abroad, respectively in Syria and Iraq conflicts causes also psychological consequences. The fact that commission of these criminal offences occasionally is encouraged by influential persons in mainstream religion such as imams of the mosques (Note 17) may manifest unpredictable effects concerning the extent of this criminal phenomenon, especially related to persons which consider these conflicts favors who like for "Islamic Jihad"-its establishing, expanding and strengthening.

The fact this criminal phenomenon currently is not being fought good enough dictates to loss of trust of citizens in regeneration of the justice system and in their perspective and of country in general. This situation normally fades away the interest of citizens in daily activities of life, but especially concerning their cooperation to bodies establishing the criminal justice system (police, prosecution, courts and prisons).

The criminal offence of Kosovo citizen's participation in armed conflicts abroad, respectively in Syria and Iraq conflicts causes also individual and family consequences of those that in any other way have been included in conflicts in question. Due to these circumstances 57 Kosovo citizens lost their life because of the fact having been participants in these armed conflicts in these two countries as well as 114 Kosovo citizens got wounded. On the other hand, after returning home have been arrested and are subject of judicial proceedings 34 persons. All those caused problems to their families related to the loss of life of the most beloved ones, financial issues etc., Individual and family problems are linked to the loss of perspective of those persons themselves, but also to their families. Many of them interrupted their education, work and real perspective. Such consequences have been manifested in the highest degree to those individuals which took their children and wives. Observing in this context, Kosovo Police statistics indicate that concerning military conflicts in Syria and Iraq currently are also 38 women and 27 children several of which have been directly included.

\subsection{Several Personal Data of Perpetrators}

Criminality in general, therefore also some types of criminality in particular, cannot be explained in their all complexity without being studied and resolved also several personal and social data of these behaviors, due to the fact criminality as a general phenomenon is manifested through commission of concrete criminal offences (Note 18). By bearing in mind this fact, in the following of this scientific paper shall be handled the age, gender, education 
level and social affiliation of perpetrators of criminal offences of Kosovo citizen's participation in armed conflicts abroad.

\subsubsection{Age}

Age is an important characteristic of criminal phenomenon that has special significance in explaining criminal behaviors (Note 19). Statistical data from judicial practice as well as criminological research data prove that perpetrators belong to persons of different ages. This fact is present to all criminal offences, thus to the criminal offence of Kosovo citizen's participation in armed conflicts abroad. Modest results of this article prove that as perpetrators of this criminal offence are mostly adults. These data shall be presented in the following table.

Table 2. The age of persons arrested and detained being in criminal proceedings

\begin{tabular}{ll}
\hline Age of persons arrested and detained being in criminal proceedings & Number \\
\hline $14-18$ & 00 \\
$18-28$ & 09 \\
$28-38$ & 21 \\
$38-48$ & 04 \\
48 onwards & 00 \\
In total & 34 (Note 20) \\
\hline
\end{tabular}

According to these data the criminal offence of Kosovo citizen's participation in armed conflicts abroad, respectively conflicts in Syria and Iraq to the greatest extent have committed persons aged between 28-38 years old in 21 cases, and then come persons who belongs age between 18-28 years old in 9 cases and persons aged 38-48 years old in 4 cases. The commission of greatest number of this criminal offence by persons of abovementioned ages is explained by the fact persons of these age-groups is considered to dedicate more to religious gatherings and users of social networks through which they have been inspired to serve to "Holly War" for "Islamic Jihad".

\subsubsection{Gender}

Also gender, similar as age represents an important characteristics of criminal phenomenon that has a particular significance in explaining criminal behavior. There is a general impression that criminality is a typical phenomenon of masculine gender (Note 21). Numerous researches conducted about different forms of crimes in many world countries prove this fact (Note 22). This conclusion is also sustainable regarding the criminal offence of Kosovo citizen's participation in armed conflicts abroad, respectively conflicts in Syria and Iraq. The data concerning arrested and detained persons to whom The State Prosecution issued a decision on investigations indicate that as a subject of these criminal offences exclusively were males (Note 23). The causes of this situation should be sought in the existence of Muslim religion world view strengthened through centuries in these lands, over inferior and subordinate position of female in society. Such a position of female probably 
continues to be present also nowadays within families from which derived persons alleged to have committed the criminal offence in question. This subordinate position as it seems excludes female also from participation in armed conflicts.

\subsubsection{Education Level}

Numerous criminological researches consider education as an important factor in preventing criminality. This fact is proven also in modest results of this scientific paper. In the following table shall be presented the degree of arrested and detained persons participation against whom The State Prosecutor issued a decision on investigations concerning the criminal offence of Kosovo citizen's participation in armed conflicts abroad, respectively conflicts in Syria and Iraq based on education level of persons that currently are subject of criminal proceedings.

Table 3. The educational level of arrested and detained persons who are subject of criminal proceedings

Education level of arrested and detained persons who are subject of Number criminal proceedings

Without elementary school completed

Elementary school completed

High School completed

Superior education

In total

\section{3}

13

18

00

34 (Note 24)

According to these data the greatest number of arrested and detained persons against whom The State Prosecution has issued a decision on investigations for the commission of criminal offence of Kosovo citizen's participation in armed conflicts abroad, respectively conflicts in Syria and Iraq belongs to persons who completed their high school. These persons participate in the commission of these criminal offences in 18 cases, and then come persons who completed only elementary school in 13 cases and persons without elementary school completed (only completed several grades of elementary school) in 3 cases. These data prove for a relatively low level of perpetrators of this criminal offence, a factor which has influenced in them to be easier manipulated in others agendas, including those related to goals of armed conflicts in Syria and Iraq.

\subsubsection{Social Situation}

Numerous data from judicial practice and researches from criminological research prove that the greatest number of perpetrators of criminal offences derive from unemployment persons and with difficult economic situation (Note 25). This fact is proven also in modest results of this scientific paper. In the following table shall be presented data on social affiliation of arrested and detained persons to whom The State Prosecutor has issued a decision on investigations for the commission of criminal offence of Kosovo citizen's participation in armed conflicts abroad, respectively conflicts in Syria and Iraq. 
Table 4. Social affiliation of arrested and detained persons who are subject of criminal proceedings

Social situation of arrested and detained persons who are subject of criminal Number proceedings

Employed

Unemployed

In total
06

28

34 (Note 26)

According to these data from 34 arrested and detained persons against whom the State Prosecutor has issued a decision on investigations for the commission of criminal offence of Kosovo citizen's participation in armed conflicts abroad, respectively conflicts in Syria and Iraq, 28 of them were unemployed persons. The commission of such a high number of this criminal offence from unemployed persons can be explained by difficult economic situation of country and the lack of perspective of citizens concerning their employment. It is considered that majority of these persons have been included in the commission of this criminal offence based on promises related to high payments that they would get during their stay and participation in armed conflicts in these two countries. On the basis of this fact it can be concluded that by increasing employment and social welfare of citizens these cases of commission of this criminal offence shall be reduced perhaps even eliminated.

\section{Several Causes of Kosovo Citizen's Participation in armed Conflicts Abroad Related to Conflicts in Syria and Iraq}

In appearance of the criminal offence of Kosovo citizen's participation in armed conflicts abroad, respectively conflicts in Syria and Iraq influence numerous general and special factors. As factors which greatly influence in appearance of this criminal offence shall be considered: economic, ideological, micro-group and the media factors.

\subsection{Economic Factors}

The criminal offence of Kosovo citizen's participation in armed conflicts abroad, respectively conflicts in Syria and Iraq, as well as other criminal offences has its roots and causes in direct and concrete socio-economic conditions of people in a particular society and country (Note 27). A very low level of Kosovo economic development which is as a consequence of the war which plagued this country but also other circumstances related to the post-war period (bad governance of the country, problematic privatization of SOE-s, weak rule of law, the lack of foreign investments etc.) is manifested in all spheres of life. Consequently Kosovo has the highest level of unemployment in Europe, a very high level of poverty, education and sciences etc. These circumstances dictate to people to develop primitive habits and backward mentalities, affinity for gambling, alcoholism, vagrancy, illegal migration (Note 28), parasitism and other negative attributes. In such circumstances is expectable that criminal behaviors to be frequent.

Among economic factors with a special importance in the appearance of the criminal offence of Kosovo citizen's participation in armed conflicts abroad, respectively conflicts in Syria and Iraq are unemployment and difficult economic conditions of life. During the conducted 
research concerning this criminal phenomenon has been concluded that the greatest number of its perpetrators is unemployed. Thus, from 34 arrested and detained persons for whom state prosecutor has issued a decision on investigations 28 of them were unemployed. Therefore, it is considered by that increasing employment it shall be influenced not only in increasing incomes in economy and in increasing the level of personal and social standard, as well as in establishing scientific, cultural and education level, and in reducing criminality in country, including the phenomenon that is a topic of this scientific paper.

Besides unemployment, also difficult economic conditions of life are considered economic factors with special influence in the appearance of the criminal offence of Kosovo citizen's participation in armed conflicts abroad, respectively conflicts in Syria and Iraq. So, during the research of this criminal phenomenon has been concluded that the greatest number of perpetrators of the criminal offence in question had a difficult economic situation. Observed in these terms, from 34 arrested and detained persons against which state prosecutor has issued a decision on investigations 30 of them had poor economic situation.

Therefore, it can be concluded that unemployment and difficult economic conditions of life represent socio-economic and social factors with significant impact in the appearance of criminality in general and the phenomenon of Kosovo citizen's participation in armed conflicts abroad.

\subsection{Ideological Factors}

In the appearance of the phenomenon of Kosovo citizen's participation in armed conflicts abroad, respectively conflicts in Syria and Iraq the main influence had probably ideological factors. In the concrete case is meant to religious indoctrination, respectively Islamic. Consequently, many circumstances created after the war presented appropriate ground that in Kosovo to enter individual groups of people which as their mission had indoctrination of people by extreme ideas and point of views, especially of religious character, such that were not known before by history of this country.

By being well trained, individuals and groups of people of Islamic extremism achieved to appropriate many imams and other individuals who had significant influence to Muslim believers. Manners of this acquisition results to have been varied but attraction in the most successful way is considered to be realized through the misuse of numerous funds concerning construction of mosques, the origin of which in many cases has been totally suspicious (Note 29), but also through distribution of individual payments. By using these and other acting manners such individuals and extreme groups achieved after more than sixty years to regain in Kosovo clothing elements that does not coincide with the traditional and modern of this country's population (the headscarf, hijab etc.). So, nowadays in Kosovo cities and villages there are not few covered women and men with beards and clothing considered to be "extreme" (short pants with special format).

Muslim extreme ideological indoctrination in Kosovo in a special way has been spread through so called problematic lectures: which were delivered by some preachers of Muslim religion to citizens in mosques and other religious meetings (for example during religious ceremonies of funerals), through which they were incited, especially young people to join terrorist organizations in Syria and Iraq in their "holy" war for Islamic Jihad. 
Indoctrination has been manifested also through sharing lectures by many imams from Kosovo and Macedonia to social networks. So, is proven by fact that all 34 arrested and detained persons against which state prosecutor has issued a decision on investigations for the commission of the criminal offence of Kosovo citizen's participation in armed conflicts abroad, respectively conflicts in Syria and Iraq, in their statements given to police have emphasized for their participation in these conflicts have been inspired by lectures of imams of mosques and other influential persons through which these conflicts were addressed as a "holy war" and possibility to gain in "eternal" life the status of "martyr".

Therefore, it is duty of responsible state institutions of the country to strengthen control at the border points and to suspicious organizations who exercise activities of humanitarian and business character (Note 30) in order to criminally prosecute individuals and groups of people which by their activities have committed respective criminal actions, respectively to prevent the further spreading of the phenomenon of Kosovo citizen's participation in armed conflicts abroad.

\subsection{Micro-Group Factors}

As a factor with special importance in the appearance of criminal offences, including the criminal offence of Kosovo citizen's participation in armed conflicts abroad, respectively conflicts in Syria and Iraq are considered to be also several institutions, communities or society cells in which a modern human being passes the biggest part of its life. As such communities shall be considered family, school and social environment. The influence of these communities is expressed especially in cases when they don't exercise or poor exercise authorizations determined by the law.

Modest results of this scientific paper prove undoubtedly that about $3 / 4$ of arrested and detained persons for which state prosecutor has issued a decision on investigations for the commission of criminal offence of Kosovo citizen's participation in armed conflicts abroad derived from families to which are cultivated religious relicts, had a relatively weak successes in learning and manifested a relatively high degree of inadequacy with environmental regulations.

Faced with this situation is estimated to be an urgent duty of Kosovo families, schools and other institutions where people pass a long period of their lives to be coherent to their responsibilities, in terms of preventing children and pupils into criminality. This is also due to the fact according to Kosovo Police statistics in war zones of Syria and Iraq there are already 27 children from Kosovo some of them (although is not known their accurate number) are included directly in armed conflicts.

\subsection{Poor Activity of State Bodies}

In criminological literature prevails the opinion that as an influential factor in the appearance of criminal offences, including the criminal offence of Kosovo citizen's participation in armed conflicts abroad undoubtedly presents the weaknesses accompanying police activity in detecting this criminal offence as well as its perpetrators; State Prosecution activity reflecting delays in investigations, support of investigations based on suspicious and incomplete evidences, court activity through bringing unlawful decisions and prison activities which are manifested through improper development of the re-socialization process (Note 31). 
The current reality proves that work of these bodies in performing their responsibilities determined by the law is marking extreme stagnation. This fact is proven by a big number of pending cases, the number of prisoners which get out of the prison whenever they want and however they want etc. (Note 32). But more convincing is the fact of addressing the activity of these bodies towards criminal phenomenon of Kosovo citizen's participation in armed conflicts abroad in Syria and Iraq. State Prosecution as abovementioned has issued only 34 decisions on investigations, whereas courts did not impose any punishment, while the presence of this phenomenon is considered to be many times higher, such constituting a concern for citizens of this country.

On basis of this, is a duty of all responsible persons of these institutions to increase the degree of efficiency and professionalism in their work, otherwise risks threatened to the country by the extent of religious extremism in a near future could be unbearable.

\subsection{Media}

It is known that media (literature, press, film, television, social networks, etc.) play an important role in a process of forming human, whether in positive or negative direction (Note 33). The positive impact of these means in equipping new generations and citizens in general with new knowledge and information is unquestionable. "On the other hand in criminological researches is discussed densely for the influence of mass media in the appearance of criminality" (Note 34).

The influence of media in the appearance of the criminal offence of Kosovo citizen's participation in armed conflicts abroad in Syria and Iraq is expressed through presenting misinformation, incomplete information but also through other acting forms. These acting manners mainly have been realized through social networks-internet, (Note 35) but without excluding daily press. Terrorist organizations ISIS, SALUSTRA etc., have marked a high level of using internet, including the most sophisticated manner of its use (Note 36). This is considered to be part of a propaganda machine of high technology used by ISIS in order to get to possible warriors in Europe and elsewhere in the world (Note 37).

Propaganda videos of ISIS strongly penetrated even in Kosovo. They in many cases seem to have been much more efficient in terms of recruiting warriors rather than physical contacts as in mosque or in private environments with imams (Note 38). Ways and their massive distribution makes clear that ISIS and other terrorist organizations in Kosovo and other countries have established also networks for their management. Motivation for "holy war" in Syria and Iraq except through lectures recorded on videos is made also through exciting songs such as the one from Nusret Kurtishi (Kosovo) "Fight for Allah" published on You Tube on October 19, 2014 which by mid February, 2015 was clicked more than 51,000 times, meaning it was heard about 12,000 times per month (Note 39). In fact there are plenty songs of this nature. It is sufficient to be emphasized the song of Sami Abdullahu (Macedonia) "Divine Paradise" etc. Such propaganda videos appeared to have been very successful in brainwashing of many young people and their joining to armed conflicts in Syria and Iraq (Note 40). Of course, problems in themselves constitute articles in newspapers and magazines which may numerous. In this regard, there is an impression that ISIS, SALUSTRA etc., possess a large network of people which their mission is to address these issues, respectively 


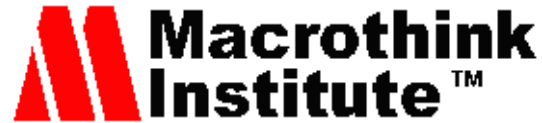

finding the ways of placing information they want in newspapers and magazines of many countries.

\section{Conclusion}

Modest results of this scientific paper led me to these conclusions:

1) By the criminal offence of Kosovo citizen's participation in armed conflicts abroad is implied actions through which is made organization, recruitment, financing, incitement, leading or training of persons or group of persons in order to join or participate in foreign army or police, in foreign army and police formations, in individual and group organizations or in any form of armed conflicts outside of the territory of Republic of Kosovo. These actions violate the state interest and national security.

2) As a perpetrator of this criminal offence of Kosovo citizen's participation in armed conflicts abroad is considered to be any person-Kosovo citizen which participates or organizes, recruits, finances, incites, leads or trains persons or group of persons in order to join or participate in foreign army or police in foreign army and police formations, in individual and group organizations or in any form of armed conflicts outside of the territory of Republic of Kosovo. As a perpetrator of this criminal offence may be also A Kosovo citizen which publicly at meeting or through writing audio-visual recordings, by including and not limited to social networks or in any other form of communication, calls up of incites others for the commission of actions establishing this criminal offence, or which conceals or does not report for the preparation of the criminal offence and who give shelter or helps the perpetrator to avoid detection, arrest, concealment of evidences etc.

3) Criminal liability for the commission of the criminal offence of Kosovo citizen's participation in armed conflicts abroad exists only when this criminal offence is committed by intent. So, criminal liability for this type of criminal offence cannot result from actions committed by negligence.

4) Against perpetrators of the criminal offence of Kosovo citizen's participation in armed conflicts abroad depending on the committed action and the degree of security risk and Kosovo national interest, it shall be imposed a sentence by imprisonment from 6 months up to 15 years. This highness of punishment is considered to be relatively high, but of course in full accordance with the degree of risk this criminal offence representing to society.

5) Conducted researches prove that currently in armed conflicts in Syria and Iraq there are 314 Kosovo citizens, which develop military actions in supporting terrorist organizations ISIS, SALUSTRA etc. $54 \%$ of these citizens have gone to these countries in 2013. Among Kosovo citizens who are in Syria and Iraq there are 27 children and 38 women, some of which are included directly in armed operations. Until now in these fighting were killed 57 Kosovo citizens. Concerning this criminal offence until now have been issued 34 decisions on investigations, whereas has not been concluded any court trial that would result with imposition of any judgment.

6) The criminal offence of Kosovo citizen's participation in armed conflicts abroad causes numerous and diverse consequences. Consequences caused by this criminal offence in general may be of political, psychological, family and individual character. This criminal offence may effect in integration of country in Euro-Atlantic structures, and manifests 
consequences in the loss of people's lives, but also social consequences for particular individuals and families.

7) In the appearance of the criminal offence of Kosovo citizen's participation in armed conflicts abroad, respectively in conflicts in Syria and Iraq influence numerous general and special factors. As factors which greatly influence in the appearance of this criminal offence are considered: economic, ideological, micro-group and media factors. Among these factors a special importance must have had lectures of imams of mosques delivered to social networks or held in mosques and other environments through which were incited persons to join various organizations in Syria and Iraq for the so-called "holy war" that coincides to the idea for establishment and extent of "Islamic Jihad".

\section{References}

Ačimović, M. (1976). Pravci kriminal nepsihologije, Beograd.

Blumi, I. (2005). Political islam Among the Albanians: Are the Taliban Coming to the Balkans. KIPRED. Retrieved from http://www.kipred.org/advCms/documents/14714_Political_islam_Among_the_Albanians_A re_the_Taliban_coming_to_the_Balkans.pdf

Case of imam of Great Mosque in Pristina, imam of a mosque in Gjilan, Busuvate of Kamenica etc. Newspaper Express, July 27, 2015,

CBS news. (2014). ISIS recruits fighters through powerful online campaign. CBS News. $\begin{array}{llll}\text { Retrieved } \quad \text { August } & \text { 29, from }\end{array}$ http://www.cbsnews.com/news/isis-uses-social-media-to-recruit-western-allies/,

Center for Security Studies, Rapport on causes and circumstances of Kosovo citizen's inclusion as foreign warriors in Syria and Iraq, Kosovar, Pristina, 2015, Code No. 04/L-123,

Criminal records and decisions of State Prosecutor concerning the criminal offence of Kosovo citizen's participation in armed conflicts abroad for the period of time 2013-2016,

Elezi, I., \& Kaqupi, S. S. (1999). Commentary of the Criminal Code of the Republic of Albania, Tirana.

Erin, M. S., \& Charlie, W. (2014). Islamic State: The Changing Face of Modern jihadism. Quillam Foundation. Retrieved from http://www.quilliamfoundation.org/wp/wp-content/uploads/publications/free/islamicstate-thechanging-face-of-modern-jihadism.pdf

Group of authors. (1973). The Criminal Law of the Republic of Albania, Tirana.

Hajdari, A. (2006). Organized criminality, Pristina.

Halili, R. (1987). Criminality against marriage and family in SAP Kosovo, Pristina.

Halili, R. (2000). Criminology, Pristina.

Hysi, V. (2012). Criminology, Tirana.

Internet World Stats. (2014). Internet users in Europe. Internet World Stats Usage and Population Statistics. Retrieved from June 30, 2014, http://www.internetworldstats.com/stats4.htm.

Kosovo Police rapport presented by the Minister of Internal Affairs of Kosovo in the committee for security of the Assembly of Kosovo on July 21, 2016, 
Kupčević - Mladjenović, Radmila. Criminology, Sarajevo, 1974, Law No. 04/L-140.

Law on the Prohibition of the Union in Armed Conflicts Abroad (Law No. 05/L-002).

Milutinoviq, M. (1984). Criminology, Pristina.

Mladinović, V., \& Konstatinović, S. (2004). Kriminalitet maloletnika, Belgrade.

Newspaper Express, September 17, 2014.

Salihu, I., \& Hasani, F. Z. H. (2014). The Criminal Code of the Republic of Kosovo, Commentary, Pristina.

Salihu, I. (2012). Criminal Law, General Part. Pristina.

Salihu, I. (2014).Criminal Law, Special Part, Pristina.

\section{Notes}

Note 1. See: Law No. 05/L-002. This law has been promulgated by decree of the President No. D1-003-2015, date March 25, 2015. The issuance of this law has been dictated by a relatively big number of Kosovo citizens which from 2013 onwards have been recruited within terrorist organizations ISIS, SALUSTRA etc., included in armed conflicts in Syria and Iraq.

Note 2. Compare: Salihu Ismet. Criminal Law, Special Part, Pristina, 2014, p. 436.

Note 3. Compare: Salihu Ismet, Hasani Fejzullah dhe Zhitija Hilmi, The Criminal Code of the Republic of Kosovo, Commentary, Pristina, 2014, p. 573.

Note 4. Salihu Ismet. Criminal Law, General Part,. Pristina, 2012, p. 188, Group of authors, The Criminal Law of the Republic of Albania, Tirana, 1973, p. 201 and Elezi Ismet, Kaqupi Skënder S. etc., Commentary of the Criminal Code of the Republic of Albania, Tirana, 1999, p. 96.

Note 5. As a perpetrator of this criminal offence shall not be considered Kosovo citizens which hold the citizenship of foreign state and are part of army or their military formation, or serve in military formations under the control of governments internationally accepted or international organizations, and neither persons which are part of security sector structures of the Republic of Kosovo, which based on the law operate outside of the territory of the Republic of Kosovo.

Note 6. Salihu Ismet. Criminal Law, General Part,.., p. 188.

Note 7. Ibid. p. 414.

Note 8. See: Code No. 04/L-123 and the Law No. 04/L-140.

Note 9. The most evident example for this is the case of Lavdrim Muhaxheri, one of the most active Kosovar in organizations and fighting operations in Syria, and probably broader.

Note 10. See: Newspaper Express, September 17, 2014, p. 7. All these persons have been arrested for incitement of religious hate and Islamic extremism that did not belong to any basic incrimination included in the Criminal Code of the Republic of Kosovo. Due to this reason all of them were released in a period of time between 15 up to 30 days. This was probably the reason for Kosovo to work in issuance of the special law-The Law on Prohibition of the Union in Armed Conflicts Abroad, which as it appears had an important 
effect in prevention of a considerable number of persons expectable that would join various organizations participants in armed conflicts in Syria and Iraq.

Note 11. See: Kosovo Police rapport presented by the Minister of Internal Affairs of Kosovo in the committee for security of the Assembly of Kosovo on July 21, 2016.

Note 12. Ibid.

Note 13. Compare: Halili Ragip. Criminality against marriage and family in SAP Kosovo, Pristina, 1987, p. 84.

Note 14. See: Kosovo Police rapport presented by the Minister of Internal Affairs of Kosovo in the committee for security of the Assembly of Kosovo on July 21, 2016.

Note 15. Ibid.

Note 16. Currently for corruption in Kosovo have been punished 11 judges and prosecutors and against 27 others are being conducted judicial procedures.

Note 17. See the case of imam of Great Mosque in Pristina, imam of a mosque in Gjilan, Busuvate of Kamenica etc. Newspaper Express, July 27, 2015, p. 7.

Note 18. Ačimović Mihajlo. Pravci kriminal nepsihologije, Beograd, 1976, pp. 7-8.

Note 19. Halili Ragip. Criminology, Pristina, 2000, p.76.

Note 20. See: Criminal records and decisions of State Prosecutor concerning the criminal offence of Kosovo citizen's participation in armed conflicts abroad for the period of time 2013-2016.

Note 21. Halili Ragip. Criminology,...,p. 77.

Note 22. Ibid, pp. 77-78.

Note 23. See: Criminal records and decisions of State Prosecutor concerning the criminal offence of Kosovo citizen's participation in armed conflicts abroad for the period of time 2013-2016.

Note 24. Ibid.

Note 25. Hysi Vasilika, Criminology, Tirana, 2012, p. 134.

Note 26. See: Criminal records and decisions of State Prosecutor concerning the criminal offence of Kosovo citizen's participation in armed conflicts abroad.

Note 27. Mladinović Vladimir, Konstatinović Spasoje. etc., Kriminalitet maloletnika, Belgrade, 2004, p. 12.

Note 28. According to incomplete data it is considered from Kosovo these five last years have migrated in countries of European Union (mostly in Germany, Austria and France etc.) and in USA and other continents over 230.000 citizens.

Note 29. Kosovo of post-war period the number of constructed mosques from suspicion funds it has quintupled. These funds have been totally outside of the state control.

Note 30. Blumi Isa (2005). "Political Islam Among the Albanians: Are the Taliban Coming to the Balkans". KIPRED. Retrieved from http://www.kipred.org/advCms/documents/14714_Political_islam_Among_the_Albanians_A re_the_Taliban_coming_to_the_Balkans.pdf.

Note 31. See more: Hajdari Azem, Organized criminality, Pristina, 2006, pp. 238-241. 


\section{Macrothink}

Note 32. See more: Center for Security Studies, Rapport on causes and circumstances of Kosovo citizen's inclusion as foreign warriors in Syria and Iraq, Kosovar, Pristina, 2015, pp. 61-77.

Note 33. Milutinoviq Milan. Criminology, Pristina, 1984, p. 403.

Note 34. Kupčević - Mladjenović, Radmila. Criminology, Sarajevo, 1974, pp. 170-171.

Note 35. Internet World Stats (2014). "Internet users in Europe". June 30, 2014.Internet World Stats Usage and Population Statistics. Retrieved from http://www.internetworldstats.com/stats4.htm

Note 36. Erin Marie Saltman and Charlie Winter (2014). "Islamic State: The Changing Face of Modern jihadism". Quillam Foundation. Retrieved from http://www.quilliamfoundation.org/wp/wp-content/uploads/publications/free/islamicstate-thechanging-face-of-modern-jihadism.pdf

Note 37. CBS news (2014). "ISIS recruits fighters through powerful online campaign". August 29, 2014. CBS News. Retrieved from http://www.cbsnews.com/news/isis-uses-social-media-to-recruit-western-allies/

Note 38. Rapport on causes and consequences,..., p. 80.

Note 39. The song speaks how it should be joined and helped "brothers" to Syria, where it could be found the healing for personal sins.

Note 40. Center for Security Studies, Rapport on causes and consequences,..., pp. 81-82.

\section{Copyright Disclaimer}

Copyright for this article is retained by the author(s), with first publication rights granted to the journal.

This is an open-access article distributed under the terms and conditions of the Creative Commons Attribution license (http://creativecommons.org/licenses/by/3.0/). 